\title{
Erratum to: EGREPA 2010 Conference
}

\author{
Seniors in the 21 st century-physical activity a tool for health, fitness and social \\ integration Prague, September 23-25, 2010
}

Published online: 17 November 2010

(C) European Group for Research into Elderly and Physical Activity (EGREPA) 2010

\section{Erratum to: Eur Rev Aging Phys Act DOI 10.1007/s11556-010-0064-7}

Unfortunately, there were errors in the published abstracts:

1. The first abstract of Valizadeh, Ghanbarzadeh \& Hosseini was missing.

2. The second abstract contained typing errors in the title. The authors were R. Valizadeh, M. Nikbakht, A.S. Hosseini \& M. Davodi.

(1)

The effect of 8 weeks aerobic exercise of run on the mental health (Physical complaint, Anxiety, Disorder in Social adequacy, Depression) of male personnel 45-55 years of national iranian south oil company portal

R. Valizadeh ${ }^{1}$, M. Ghanbarzadeh ${ }^{2}$, A. S. Hosseini ${ }^{3}$

${ }^{1}$ Faculty of physical Education \& Sport Science,

Islamic Azad University, Omidieh Branch, Iran

${ }^{2}$ Faculty of physical Education \& Sport Science,

Shahid Chamran University, Ahvaz, Iran

${ }^{3}$ Faculty of physical Education \& Sport Science,

Islamic Azad University, Behbahan Branch, Iran

The online version of the original article can be found at http://dx.doi. org/10.1007/s11556-010-0064-7.

\begin{abstract}
Introduction
Depression and anxiety are both disorders that between 9 to $26 \%$ of women and 5 to $12 \%$ of men have been complain from them (1). So the aim of this research was the examination of the effect of 8 weeks aerobic exercise of run on the mental health (Physical complaint, Anxiety, Disorder in Social adequacy, Depression) of male personnel 45-55 years of national iranian south oil company portal.
\end{abstract}

\section{Methods}

This is a semi experimental study that has been done by experimental and control group. For evaluation of mental health the questionnaire GHQ-28 Cold Berg and Hiller (1979) was used. In this research the population of research was all male personnel $(n=500)$ (age 45-55) of national iranian south oil company portal. After their mental health evaluation with a 1.5 upper standard deviation of mean 40 members was selected and divided randomly in two groups. Statistical analysis has been done by computer and SPSS program with the use of $T$-test statistical method.

\section{Results and discussion}

The findings show that aerobic exercise of run has a significant effect on mental health, anxiety and depression. Comparing the scores of two groups in post-test indicate that practical group has shown lower score in these variables in compare with control group. Also comparing the scores mean of physical complain and disorder in social adequacy between experimental and control group shows that aerobic exercise of run dose not have significant effect 
on these variables. Since the levels of hormones such as norepinephrine, serotonin and dopamine in the body of people who suffer from depression and anxiety is low, it seems that aerobic exercise of run has been able to increase levels of these hormones.(2)

\section{Conclusion}

Persons suffering from mental disorders are recommended to do aerobic exercise for $30 \mathrm{~min}$, three times a week with intensity of 60 to $70 \%$ of $\operatorname{MHR}(3)$, in order to reduce the pressure of these disorders.

\section{References}

1-Robin L.N., Helzer J.E., Weissman M.N., Graenberg E., (1984). "Lifetime prevalence of specific psychiatric Disorders in three sites Archives of General psychiatry", 41(7) 949

2-Gaszkowska M. (2004). "Effect of exercise on anxiety and mood psychiatrpoblish", 38(4) 611-20
3-Netz Y, Wumeny J, Backer BJ, Tenenbaum G (2005). Physical activity and psychological well-being in advanced age: A meta analysis of intervention studies. Psychol Aging 20(2) 272-284.

(2)

Study of the effect of 8 weeks of elected aerobic work on the density of fatness of liver cells for citizens of Shooshtar town suffering from fat liver (steatuhepatit).

Valizadeh $\mathrm{R}^{1}$,Nikbakht $\mathrm{M}^{2}$, Hosseini A $\mathrm{S}^{3}$, Davodi $\mathrm{M}^{4}$, 1-Faculty of physical Education \& Sport Science, Islamic Azad University, Omidieh Branch, Iran 2-Faculty of physical Education \& Sport Science, Islamic Azad University,Shooshtar Branch, Iran 3-Faculty of physical Education \& Sport Science, Islamic Azad University,Behbaham Branch, Iran 4-Shahid hamran University 